\title{
Protist 18S rRNA gene sequence analysis reveals multiple sources of organic matter contributing to turbidity maxima of the Columbia River estuary
}

\author{
Lydie Herfort $^{1, *}$, Tawnya D. Peterson ${ }^{1}$, Lee Ann McCue ${ }^{2}$, Peter Zuber ${ }^{1}$ \\ ${ }^{1}$ Center for Coastal Margin Observation \& Prediction and Division of Environmental \& Biomolecular Systems, \\ Oregon Health \& Science University, 20000 NW Walker Rd, Beaverton, Oregon 97006, USA \\ ${ }^{2}$ Pacific Northwest National Laboratory, 902 Battelle Boulevard, Richland, Washington 99352, USA
}

\begin{abstract}
The Columbia River estuary is traditionally considered a detritus-based ecosystem fueled in summer by organic matter (OM) from expired freshwater diatoms. Since estuarine turbidity maxima (ETM) are sites of accumulation and transformation of this phytoplankton-derived $\mathrm{OM}$, a project was undertaken to further characterize the ETM protist assemblage by collecting and analyzing bottom and surface water samples throughout an ETM event in August 2007. Biogeochemical, microscopic and molecular (18S rRNA gene clone libraries) analyses were performed. The data confirmed that the majority of the particulate OM in ETMs is derived from chl apoor particulate organic carbon tagged by DNA that is too damaged to be detected by molecular analysis. The phylogeny of the diatoms uncovered in our clone libraries demonstrated that the fresh, labile particulate OM fraction of the ETM has a marine origin. In addition, the detection of DNA from dead Myrionecta rubra cells from red tide bloom decay in the pre-ETM bottom waters suggests a transient autochthonous input into the OM pool of estuarine bottom waters. Furthermore, the discovery of Katablepharis sequences associated with the ETM event during a period when this flagellate is not abundant in the estuary water column indicates that ETMs enable the retention of this microeukaryote within the estuarine system. These findings challenge the traditional view of freshwater-derived detritus-based turbidity maxima, and imply multiple sources of OM to the Columbia River ETMs. These ETMs are thus sites of effective transformation of freshwater, marine and estuarine OM inputs, as well as refugia for ecologically relevant protists.
\end{abstract}

KEY WORDS: Estuarine turbidity maxima $\cdot$ Columbia River estuary $\cdot$ Organic matter

\section{INTRODUCTION}

The Columbia River is the second largest North American river in terms of annual river discharge $(2 \times$ $10^{11} \mathrm{~m}^{3} \mathrm{yr}^{-1}$ ) (Frey et al. 1984, Sullivan et al. 2001), and its large and complex coastal plume is tightly connected with its estuary, which is located in a narrow drowned river valley bordered by the states of Washington and Oregon (Fig. 1). The estuary is affected by mixed semi-diurnal tides (Jay 1984), but is also influenced by large river inputs that create a turbulent environment characterized by short residence times ( 0.5 to $5 \mathrm{~d}_{i}$ Neal 1972) and stratification which varies in strength both tidally and seasonally. The maximum river discharge occurs in late spring due to the melting of accumulated snowpack in the drainage basin throughout the winter, while the lowest discharge typically occurs in summer. The river is characterized by relatively high freshwater primary productivity (mostly diatoms) in spring and summer 


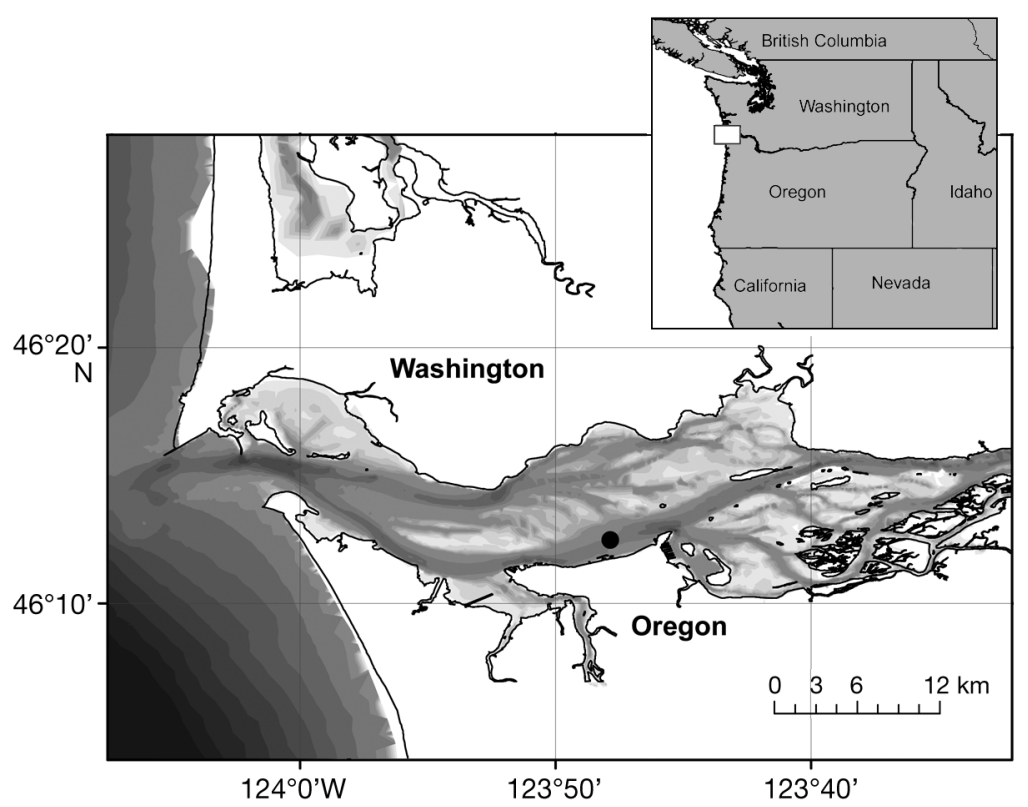

Fig. 1. Columbia River estuary, Pacific Northwest coast of the US. (•) Site of Time series sampled in August 2007 throughout an estuarine turbidity maximum (ETM) in the south channel of the estuary. Shading depicts bathymetry and highlights the estuary north and south channels (note that a different scale was used for the coast and the estuary to enhance the visualization of the estuarine channels)

(Sullivan et al. 2001). Periods of coastal upwelling of nutrient-rich water, which are coupled with heightened coastal primary productivity, are also frequent during the summer in this region.

These rich sources of primary productivity (river and ocean) do not translate into high estuarine primary productivity, however, because the high flushing times and light-limiting turbidity maintain low levels of phytoplankton standing stocks and primary production in the Columbia River estuary. Indeed, estuarine phytoplankton biomass is low because rapid flushing of the estuary provides limited time for the estuarine phytoplankton population to develop (Sullivan et al. 2001) or for riverine phytoplankton to acclimate to mixing conditions. Thus, the prevailing estuarine conditions lead to the osmotic rupture of many live freshwater phytoplankton cells, which encounter increasing salinity (with values of 1-5) as they enter the estuary (Haertel et al. 1969, Lara-Lara et al. 1990a). Since turbidity in the estuary is high (Haertel et al. 1969), light is limiting for photosynthesis and the estuarine primary productivity of this small phytoplankton standing stock is low. Therefore, most of the estuarine organic matter (OM) is in the form of detritus delivered from the adjacent river and ocean, which is then consumed by an active microbial community that can support up to $84 \%$ of the secondary production in the estuary (Simenstad et al. 1990). Thus, in contrast to most large North American estuaries, the Columbia River estuary is commonly considered a detritus-based ecosystem.

A large fraction of the estuary's secondary production (including that accomplished by zooplankton and bacteria) takes place in the estuarine turbidity maxima (ETM), which are sites of OM accumulation, heightened microbial activity, and grazing (Simenstad et al. 1994, Crump \& Baross 1996, Prahl et al. 1997, Crump et al. 1998, 1999). The Columbia River ETMs can therefore be considered as estuarine hydrodynamic traps that act as bioreactors, mediating biogeochemical reactions that transform and remove river-borne biogenic inputs. These ETMs are, therefore, essential biogeochemical interfaces between the Columbia River watershed and the coastal northwest Pacific Ocean (Prahl et al. 1997). These transient lower estuary sedimentary features are generated during tidal reversals and are formed as the deep salinity intrusion interacts with residual bottom currents (Jay \& Musiak 1996). ETMs are characterized by concentrations of suspended particulate matter $\geq 50 \mathrm{mg} \mathrm{l}^{-1}$, but their intensity varies (50 to $>200 \mathrm{mg}$ $\mathrm{l}^{-1}$ ) according to season, diurnal tidal cycles, and spring or neap tidal cycles. Larger ETMs are usually observed during spring flood tides (Small \& Morgan 1994, Small \& Prahl 2004) and are often associated with significant particle resuspension from the estuary bottom. In contrast, low amplitude (neap) tides typically allow greater trapping of river-derived particles. ETMs are thus ephemeral features that oscillate on a fortnightly time-frame, gaining new bioactive materials during neap tide stratification and eroding microbiologically transformed bioactive materials (characterized by low chl a content of the suspended particulate matter organic carbon fraction (chl a:POC)) during spring tide mixing (Small \& Prahl 2004). This trapping and resuspension continuum has been described as a conveyor belt process (Small \& Prahl 2004).

ETMs are hotspots of microbial activity (Crump \& Baross 1996, Crump et al. 1998, 1999), indicating that the $\mathrm{OM}$ accumulated during neap tides is highly 
labile. The source and nature of the OM present within ETMs have been inferred using biogeochemical approaches (Small \& Morgan 1994, Prahl et al. 1997, Small \& Prahl 2004), but detailed investigations of the phytoplankton POC have not been undertaken. Biogeochemical data support the notion that POC in the estuary water column (including ETMs) during spring and summer is dominated by expired freshwater phytoplankton (Lara-Lara et al. 1990a, Small et al. 1990, Prahl et al. 1997, Sullivan et al. 2001). However, direct inspections of protist assemblages in estuarine non-ETM waters using microscopic observations and/or analyses of partial $18 \mathrm{~S}$ rRNA gene sequences suggest that marine phytoplankton can also contribute significantly to estuarine POC (Haertel et al. 1969, Amspoker \& McIntire 1986, P. Kahn unpubl.). Although the relative contribution by marine phytoplankton varies in time (being more prevalent during the highly productive upwelling summer events) and space (being more predominant in the higher salinity bottom waters found near the mouth), marine sources should contribute to POC that is concentrated hydrodynamically in the ETM.

In order to test the hypothesis that marine taxa can contribute significantly to OM concentrated in the ETM, we analyzed the protist assemblages associated with the development of an ETM in the Columbia River estuary. This ETM occurred during a spring flood tide with low river flow, when the contribution from oceanic sources would be expected to be greatest. The objective was to estimate an upper limit for the contribution of marine OM to the estuary. In conjunction with biogeochemical and microscopic analyses, we used a molecular approach (construction of 18S rRNA gene clone libraries) to characterize the protist assemblage, since molecular studies in aquatic systems have often revealed higher levels of protist diversity than is apparent from light microscopy, including the discovery of novel lineages (e.g. Diez et al. 2001, López-García et al. 2001, Moon-van der Staay et al. 2001, Savin et al. 2004, Lefranc et al. 2005). This has especially been true for picoeukaryotes that often remain uncharacterized in microscopic observations because of missing distinctive morphological features. Given that ETMs are characterized by an elevated retention time and have been shown to host a unique particle-attached bacterial assemblage, such molecular characterization of the protist assemblage might also lead to the discovery of new unicellular picoeukaryotes that might inhabit these microbial hotspots of the Columbia River estuary.

\section{MATERIALS AND METHODS}

\section{Sample acquisition}

During a research cruise aboard the RV 'Barnes', a time series was carried out on 26 August 2007 in the south channel of the Columbia River estuary to capture a spring flood tide ETM event (see Figs. 1 \& 2). Samples were collected using a high volume, low pressure, air driven pump attached to a cage bearing a conductivity-temperature-depth (CTD) sensor (Seabird) coupled to a fluorometer and optical backscatter (FLNTU) sensor (Wetlab). Salinity values are reported using the practical salinity scale. Water samples were collected $1 \mathrm{~m}$ above the bottom at 5 time points: (1) before the ETM started to capture the background protist community, (2) as the ETM increased, (3) during the peak of the ETM, (4) as the ETM decreased, and (5) after the ETM event. Water was also collected during the peak of the ETM at $1 \mathrm{~m}$ below the surface.

\section{Light microscopy}

For cell counts, water samples $(40 \mathrm{ml})$ were fixed with formaldehyde (final concentration: $4 \%$ ) at room temperature for $1 \mathrm{~h}$ and stored at $-20^{\circ} \mathrm{C}$ for a week before being brought to the lab where they were placed at $-80^{\circ} \mathrm{C}$ until analysis. The samples were then thawed and $25 \mathrm{ml}$ was allowed to settle overnight according to the Utermöhl method (Utermöhl 1931, 1958). A minimum of 100 cells were counted per sample using an inverted microscope (Apotome, Zeiss). Our samples were collected during a bloom of the photosynthetic ciliate Myrionecta rubra in the Columbia River estuary; although this ciliate is known to be extremely fragile, the approach employed here to detect $M$. rubra cells by light microscopy has been validated in an earlier study (Herfort et al. 2011) in which (1) cells were still clearly visible when present, although they are often damaged when fixed with formaldehyde and stored frozen, and (2) similar $M$. rubra cell counts were obtained when comparing samples processed as described above to those fixed with Lugol's iodine (final concentration: $1 \%$ ) and stored at $4^{\circ} \mathrm{C}$. The abundance of protists other than diatoms, Cyanobacteria, chlorophytes and $M$. rubra (e.g. other ciliates, dinoflagellates or cryptophytes) were not determined by microscopy. Cell counts of both live (containing chloroplasts) and dead diatoms (empty diatom frustules, with no apparent chloroplasts) were directly 
estimated by light microscopic examination of formaldehyde fixed samples using the approach mentioned above.

\section{S rRNA gene clone libraries}

Nucleic acids were extracted from collected samples as described in Herfort et al. (2011). Briefly, 1 l of water was collected and immediately filtered through $0.2 \mu \mathrm{m}$ pore size Sterivex filters (PES, ESTAR, Millipore) using a peristaltic pump. Samples were then fixed with $2 \mathrm{ml}$ of RNAlater (Ambion) and stored at $-80^{\circ} \mathrm{C}$ until processing. A phenol-based extraction (Herfort et al. 2011) was performed twice for each Sterivex filter (with one Sterivex filter per sample) and extracts were combined. Eukaryotic DNA encoding 18S rRNA genes was amplified, cloned and sequenced as described in Herfort et al. (2011). Briefly, PCR was carried out using the eukaryote-specific primers EukA (5'-AAC CTG GTT GAT CCT GCC AGT-3') and EukB (5'-TGA TCC TTC TGC AGG TTC ACC TAC-3') (Diez et al. 2001). PCR products were ligated into a TOPO vector (pCR 2.1, Invitrogen) and used to transform chemically competent Escherichia coli cells (One Shot Top 10, Invitrogen). For each sample, two 96-well microtiter plates (192 clones) were sequenced at the Genome Sequencing Center at Washington University (St. Louis, MO, USA) using the primer set mentioned above.

The 2 sequences generated using primers EukA and EukB were separately submitted to BLASTN for analysis, searching the NCBI non-redundant nucleotide database (downloaded on Dec 16, 2010) for homologous sequences, because sequencing reads from the 2 primers used (EukA: position 1-20 and EukB: position 1780-1800) did not overlap (while in theory, Sanger sequencing gives $800-1000$ bp reads and thus 2 such reads - one starting at the beginning and the other at the end of the 18S rRNA genecould be long enough to meet in the middle of the $\sim 1800$ bp 18S rRNA gene; toward the end of the read, the sequence data is very poor in quality and error prone such that trying to identify the overlap would be unreliable). These data were used to screen for poor sequence reads and reads consisting of only vector sequences. The remaining results were limited to significant hits (at least 300 bases aligned, an expectation value $\leq 1 \mathrm{e}-80$, and percent identity $\geq 96 \%$ ). For each read, after filtering using the above criteria, the top BLAST hits (up to a maximum of 50 hits) were listed and evaluated to determine if the database hits for the 2 sequence reads (from EukA and EukB) of a given clone were consistent. Only those clones with consistent BLAST hits were used, which allowed us to not only eliminate chimera sequences, but also obtain a robust taxonomic affiliation that is in par with assignment by phylogenetic trees. This assignment was sometimes straightforward, e.g. with reads JF275122 and JF275123, where Myrionecta rubra was clearly a good match for this clone because for both reads, other BLAST hits in the list were less defined taxonomically, but still appropriate for this ciliate (uncultured alveolate, uncultured freshwater eukaryote, uncultured marine eukaryote, uncultured marine Mesodiniidae). Conversely, it was sometimes impossible to obtain this level of taxonomic detail, e.g. with reads JF275116 and JF275117, for which BLAST lists contained a wide range of diatom species (e.g. Cyclostephanos invisitatus, Stephanodiscus minutulus, Cyclotella bodanica, Minidiscus trioculatus, Thalassiosira aestivalis), with no actual matching top hits for the 2 reads. In this case, it was impossible to designate with confidence a specific diatom species to this clone and assignment was done at the class level (i.e. diatom). Nonetheless, for most diatom sequences in our analysis, both reads uncovered matching diatom species as top BLAST hits and it was therefore possible to specify a genus (e.g. JF275114JF275115 assigned as Skeletonema marinoi). To focus the analysis on unicellular eukaryotic assemblages (henceforth referred to as protist assemblages), 18S rRNA gene sequences belonging to multicellular organisms (e.g. copepods) were removed. This stringent processing of our sequences resulted in 35 to 81 assigned protist clone sequences per sample (see Appendix Table A1) for our final class-level analysis. The low coverage for the pre-ETM bottom water clone library (35 sequences) was due to the removal of many copepod sequences. Appendix Table A2 provides the accession numbers of all partial 18S rRNA gene sequences obtained during this study that have been submitted to GenBank (JF275104- JF275843).

\section{Pigment analysis}

Suspended particulate matter was collected by filtering water (100-300 ml) through pre-weighed GF/F filters ( $25 \mathrm{~mm} \varnothing$, Whatman). The filters were then folded, wrapped in aluminum foil, and stored at $-20^{\circ} \mathrm{C}$ in the dark until needed for photosynthetic pigment (chlorophylls and carotenoids) analysis by 
the high performance liquid chromatographic (HPLC) method of Wright et al. (1991). Briefly, pigment samples were cold-extracted $\left(-15^{\circ} \mathrm{C}\right)$ in polypropylene centrifuge tubes using a fixed volume of $90 \%$ acetone in water $(\mathrm{v} / \mathrm{v})$. Chromatographic separations were made using a reverse-phase column (Allsphere $\mathrm{C} 8,25 \mathrm{~cm} \times 4.6 \mathrm{~mm} \varnothing$, Grace) and diode array detection at $436 \mathrm{~nm}$. Quantification was accomplished using response factors for authentic standards of chl $a$ and fucoxanthin and the integrated peak area for each in the sample. No authentic standard for alloxanthin was available; thus, quantitative data for this carotenoid is reported in fucoxanthin-equivalents.

\section{Particulate organic carbon and nitrogen}

Suspended particulate matter for elemental (total organic carbon: POC, total nitrogen: PN) analysis was obtained by filtering $100-300 \mathrm{ml}$ of water onto a pre-combusted $\left(12 \mathrm{~h}\right.$ at $\left.500^{\circ} \mathrm{C}\right) \mathrm{GF} / \mathrm{F}$ filter $(25 \mathrm{~mm}$ $\varnothing$, Whatman). All filters were folded, tightly wrapped in aluminum foil and stored at $-20^{\circ} \mathrm{C}$ until analysis. The POC and PN contents of the suspended particulate matter on the acid-fumed filters (Hedges \& Stern 1984) were determined using an elemental analyzer (EA, Carlo Erba NA-1500) system that was set-up and operated as described by Verardo et al. (1990).

\section{RESULTS AND DISCUSSION}

The Columbia River ETMs are commonly considered to be sites of enhanced transformation of allochthonous OM inputs, which during the summer are derived mostly from expired river-borne diatoms (Small et al. 1990, Simenstad et al. 1994, Small \& Morgan 1994, Crump \& Baross 1996, Prahl et al. 1997, Crump et al. 1998, 1999, Sullivan et al. 2001). Although our biogeochemical data confirm that ETMs contain OM that is mostly composed of chl apoor POC, our molecular study of protist assemblages allows a clearer characterization of the contribution of other OM sources to the Columbia River ETM.

Elevated suspended particulate matter concentrations $\left(85 \mathrm{mg} \mathrm{l}^{-1}\right.$ ) confirmed the optical measurements of high turbidity in the peak ETM bottom water (Table 1, Fig. 2) and indicated that the August spring flood tide ETM event of the current study could be considered moderate according to the classification of Small \& Morgan (1994). As expected for late summer, the peak ETM bottom water had high levels of POC and PN (2.6 and $0.3 \mathrm{mg} \mathrm{l}^{-1}$, respectively), but low chl a concentration $\left(0.48 \mu \mathrm{g} \mathrm{l}^{-1}\right)$, thus resulting in a low chl a:POC ratio $\left(0.19 \mathrm{mg} \mathrm{g}^{-1}\right.$ ) (Table 1$)$. Given that ratios of chl a:POC for healthy phytoplankton range from $10-30 \mathrm{mg} \mathrm{g}^{-1}$, such a low ratio suggests that the majority of the particulate OM in the ETM is

Table 1. Physical, biogeochemical and biological characteristics of bottom waters collected in August 2007 in the Columbia River estuary south channel throughout a spring flood tide estuarine turbidity maximum (ETM), as well as of surface water sampled during the peak of bottom turbidity. nd: not determined. \% chl $a=100 \times[\mathrm{chl} a] /([\mathrm{chl} a]+[$ phaeophytin a])

\begin{tabular}{|c|c|c|c|c|c|c|c|}
\hline $\begin{array}{l}\text { Water layer: } \\
\text { ETM time point: }\end{array}$ & \multicolumn{5}{|c|}{ Bottom } & $\begin{array}{l}\text { Surface } \\
\text { Peak }\end{array}$ & \\
\hline Salinity (psu) & 5.9 & 10.3 & 12.4 & 11.8 & 13.1 & 0.9 & \\
\hline Temperature $\left({ }^{\circ} \mathrm{C}\right)$ & 19.3 & 18.3 & 17.7 & 17.8 & 17.4 & 20.4 & \\
\hline Turbidity (NTU) & 2.3 & 5.4 & 18.3 & 7.3 & 2.9 & 2.1 & \\
\hline Suspended particulate matter $\left(\mathrm{mg} \mathrm{l}^{-1}\right)$ & 9 & 16 & 85 & 79 & 19 & 7 & NOTE: Table \\
\hline Particulate organic carbon (POC) $\left(\mathrm{mg} \mathrm{l}^{-1}\right)$ & 0.54 & 0.99 & 2.61 & 1.21 & 0.86 & nd & corrected after \\
\hline Particulate nitrogen (PN) $\left(\mathrm{mg} \mathrm{l}^{-1}\right)$ & 0.07 & 0.11 & 0.27 & 0.14 & 0.11 & nd & publication. \\
\hline $\mathrm{Chl} \mathrm{a}\left(\mathrm{mg} \mathrm{l}^{-1}\right)$ & nd & 0.54 & 0.48 & 0.21 & 0.41 & 0.56 & \\
\hline Phaeophytin a (mg l'-1) & nd & 0.05 & 0.06 & 0.05 & 0.04 & 0.00 & \\
\hline Fucoxanthin $\left(\mathrm{mg} \mathrm{l}^{-1}\right)$ & nd & 0.19 & 0.29 & 0.16 & 0.23 & 0.14 & \\
\hline Alloxanthin $\left(\mathrm{mg} \mathrm{l}^{-1}\right)$ & nd & 0.04 & 0.06 & 0.03 & 0.04 & 0.05 & \\
\hline$\% \mathrm{Chl} \mathrm{a}$ & nd & 92 & 88 & 81 & 91 & 100 & \\
\hline Chl a:POC $\left(\mathrm{mg} \mathrm{g}^{-1}\right)$ & nd & 0.55 & 0.19 & 0.17 & 0.48 & nd & \\
\hline $\mathrm{POC}: \mathrm{PN}$ & 8.3 & 9.0 & 9.6 & 8.7 & 8.1 & nd & \\
\hline Live diatom (cells ml ${ }^{-1}$ ) & 92 & nd & 261 & nd & 249 & 154 & \\
\hline Diatom frustule (cells ml ${ }^{-1}$ ) & 67 & nd & 163 & nd & 148 & 148 & \\
\hline Cyanobacteria (cells ml ${ }^{-1}$ ) & 0 & nd & 0 & nd & 0 & 130 & \\
\hline Chlorophyte (cells ml ${ }^{-1}$ ) & 0 & nd & 0 & nd & 0 & 18 & \\
\hline
\end{tabular}




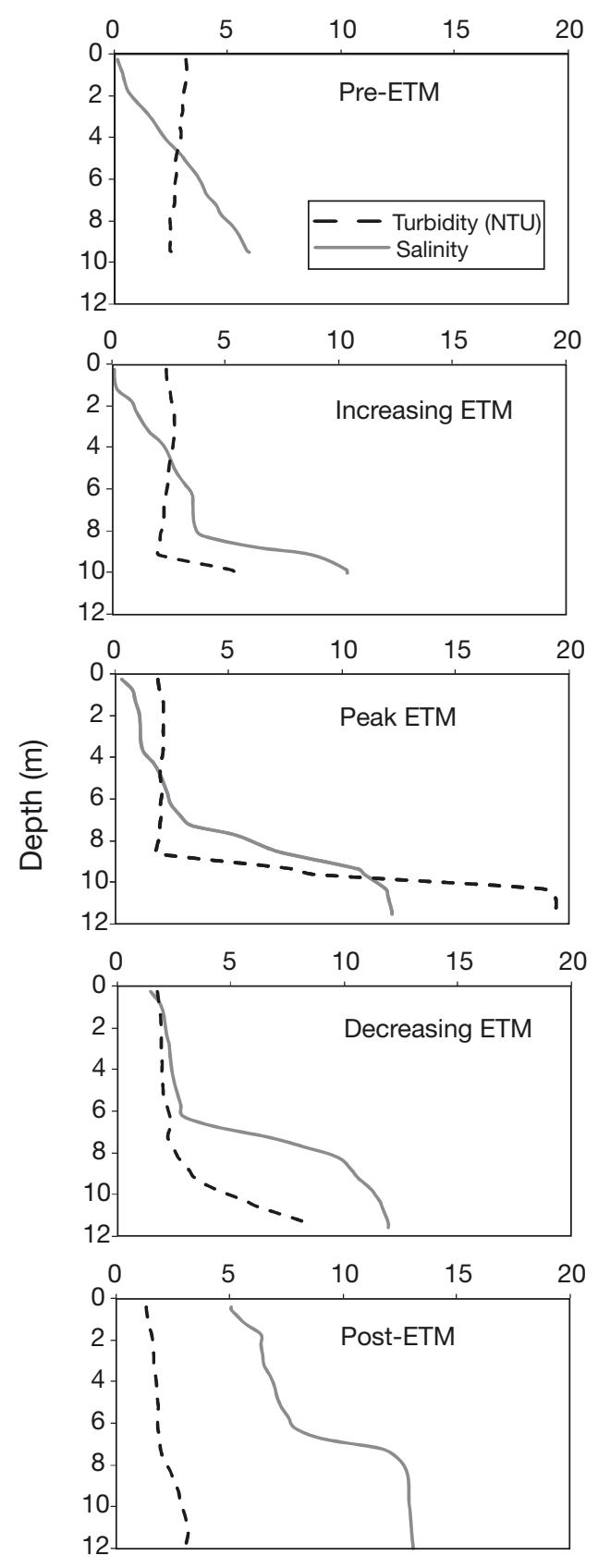

Fig. 2. Salinity and turbidity profiles of the water column during a time series carried out in the south channel of the Columbia River estuary in August 2007, showing the development of an estuarine turbidity maximum (ETM) during a flood tide. (See sampling location in Fig. 1)

derived from expired phytoplankton or soil OM (Sullivan et al. 2001 and references therein). Phytoplankton freshness can also be estimated based on the percentage of photosynthetically active chl $a=(100 \times$ $[\mathrm{chl} a] /([\mathrm{chl} a]+[$ phaeophytin a]) (Small \& Morgan 1994). The relatively low value $(88 \%)$ calculated for the peak ETM bottom water compared to that obtained for starting and post-ETM bottom (92 to $91 \%)$ or surface $(100 \%)$ waters (Table 1$)$ also indicates enhanced photosynthetic pigment degradation in peak ETM water. Therefore, the biogeochemical properties of the waters collected in the estuary during the summer of 2007 throughout a spring flood tide ETM event (Table 1, Fig. 2) agree well with prior findings in that the majority of the particulate OM of spring tide ETM is made of chl a-poor POC.

Furthermore, all 3 approaches used to assess diatom abundances (light microscopy, pigment analysis and 18S rRNA gene sequencing) confirmed an increase in diatoms in peak ETM bottom waters compared to non-ETM waters (Tables 1 \& A2, Fig. 3). Counts of live cells and empty frustules (261 and 163 cells $\mathrm{ml}^{-1}$ ) as well as concentrations of fucoxanthin $\left(0.29 \mathrm{\mu g} \mathrm{l}^{-1}\right)$ were all higher in peak ETM bottom water compared to pre- and post-ETM bottom waters (92 to 249 live diatoms $\mathrm{ml}^{-1}$ and $0.19-0.23 \mu \mathrm{g}$ fucoxanthin $\mathrm{l}^{-1}$ ) (Table 1). It should be noted that although fucoxanthin is present in a variety of algal taxa, this pigment is most commonly associated with diatoms and is thus frequently used in biogeochemical studies as a chemotaxonomic marker for diatoms (Goodwin 1971, Sullivan et al. 2001). Diatom sequences were also most prevalent in the peak and post-ETM bottom water clone libraries, representing half of all protist clones (Fig. 3, Table A2). Interestingly, when normalized to POC, fucoxanthin concentrations were lowest in high turbidity water $(24 \mathrm{\mu g}$ gPOC $^{-1}$ compared to $27-50 \mu$ gPOC $^{-1}$ for other samples), hence suggesting enhanced cell degradation (and thus again enhanced pigment degradation) in peak ETM bottom water. All these data, which now also include a widely used approach in environmental microbiology, i.e. sequencing of the small-subunit ribosomal gene, support the earlier biogeochemical findings of a largely diatom dominated particulate OM of the Columbia River ETM during the summer. Our limited biogeochemical dataset cannot distinguish between degraded marine or freshwater phytoplankton debris. However, given that a riverine origin for the particulate OM of ETMs has been demonstrated (Prahl et al. 1997), it is highly likely that the chl a-poor POC signal detected in this spring tide ETM OM was derived mostly from freshwater diatom inputs.

In contrast to prior biogeochemical studies, the analysis of 18S rRNA gene sequences allowed the phylogenetic resolution of most live or recently dead diatoms at the genus level, and at times even at the species level, enabling us to speculate on the origin (marine or freshwater) of protistan organisms in the 


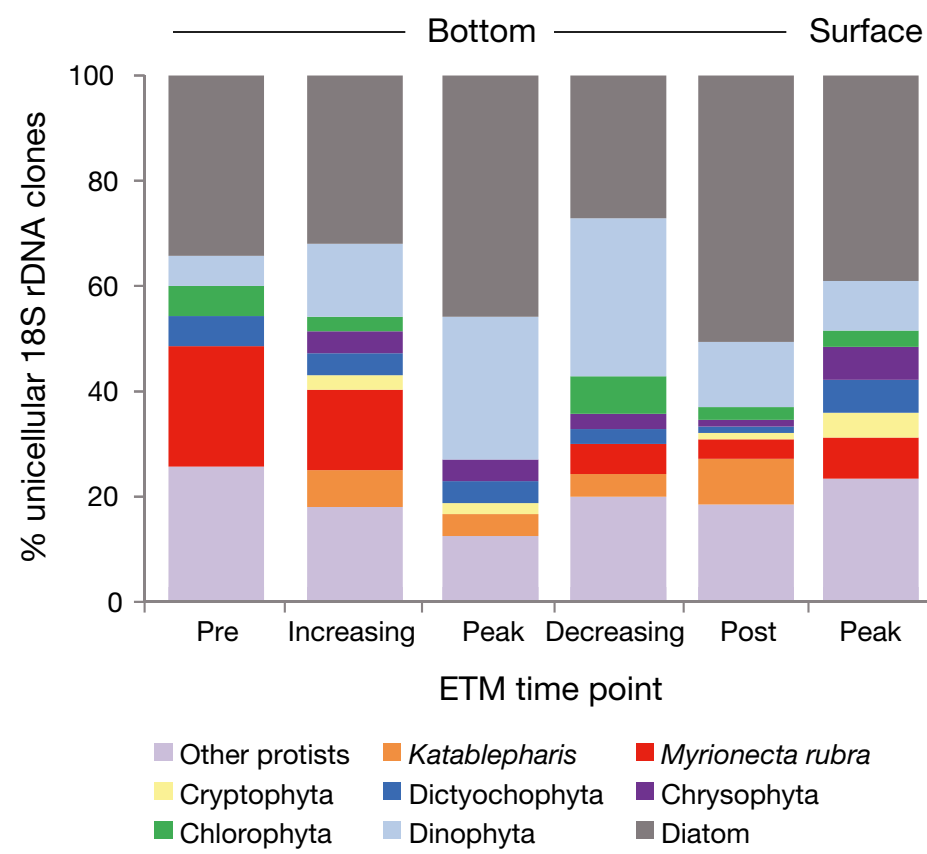

Fig. 3. Proportional contribution of different protist 18S rRNA gene sequences to the total number of unicellular clones in libraries constructed from bottom and surface waters collected in August 2007 in the Columbia River estuary south channel throughout a spring flood tide estuarine turbidity maximum (ETM). The proportions were determined using nucleotide sequence analysis of 18S rRNA amplified from DNA extracted from water samples collected during the

ETM time series. Note the dominance of diatoms in all samples

ETM. Diatoms are particularly good environmental indicators and have been extensively used both as living and fossil forms (Stoermer \& Smol 1999) because they (1) are cosmopolitan and abundant, (2) boast a high diversity of species each with a narrow ecological preference, and (3) are also relatively persistent due to the slow rate of silicate frustule decay. A high number of sequences from the marine diatom Thalassiosira was detected in all bottom water $18 \mathrm{~S}$ rRNA gene clone libraries ( 21 to $45 \%$ of total diatom clones, Table 2), while sequences of the small centric diatom Cyclotella dominated (52\%, Table 2) the diatom assemblage of the surface water collected during the peak of the ETM. Diatoms of the genus Cyclotella are found in both marine and freshwater environments but comprise distinct species in each system (Prasad et al. 1990). Sequences of the freshwater representative $C$. atomus were detected in all samples, but an additional sequence of the marine species $C$. meneghiniana was uncovered in the pre-ETM bottom water clone library (accession numbers JF275104 and JF275105 for EUKA and EUKB reads).

With this data, it is possible to calculate the proportion of abundant marine to freshwater diatoms in our clone libraries and to relate these percentages to the turbidity values of the water sampled (Fig. 4). A dominance of freshwater diatom sequences $(77 \%)$ was observed in low turbidity surface water, while an abundance of marine diatom sequences (60 to $93 \%$ ) was discovered in bottom waters which were all characterized by higher salinity values of 5.9 to 13.1 (Fig. 4). The percentage of clones is not equal to the effective abundance of each diatom; however, these numbers likely reflect broad patterns of abundance and therefore indicate that some degree of mixing between river and ocean waters has occurred in all samples, including the surface water of low salinity value of 0.9 (Table 1, Fig. 4). Besides having a high frequency of freshwater diatom sequences (Fig. 4), the surface samples also possessed a typical protist and microbial assemblage according to the microscopical analysis (diatoms, Cyanobacteria and chlorophytes; Table 1) (Haertel et al. 1969) and a high \%chl a $(100 \%$, Table 1$)$, which is indicative of a healthy

Table 2. Percentage composition (out of total diatom clones) of the most abundant diatom 18S rRNA gene sequences detected from bottom and surface waters collected in August 2007 in the Columbia River estuary south channel. The data were collected throughout a spring flood tide estuarine turbidity maximum (ETM) and revealed a high frequency of the marine diatom Thalassiosira sequences in all bottom waters. Bold values: most abundant diatom for each sample. nd: sequences not detected

\begin{tabular}{|c|c|c|c|c|c|c|c|}
\hline \multicolumn{2}{|l|}{ ETM time point: } & $\begin{array}{l}\text { Pre } \\
25\end{array}$ & $\begin{array}{c}\text { Increasing } \\
43\end{array}$ & $\begin{array}{l}\text { Bottom } \\
\text { Peak }\end{array}$ & $\frac{\text { Decreasing }}{21}$ & $\begin{array}{c}\text { Post } \\
\mathbf{4 1}\end{array}$ & $\begin{array}{c}\begin{array}{c}\text { Surface } \\
\text { Peak }\end{array} \\
12\end{array}$ \\
\hline Marine & $\begin{array}{l}\text { Thalassiosira } \\
\text { Asterionellopsis } \\
\text { Skeletonema }\end{array}$ & $\begin{array}{c}25 \\
8 \\
8\end{array}$ & $\begin{array}{c}43 \\
9 \\
9\end{array}$ & $\begin{array}{c}45 \\
18 \\
9\end{array}$ & $\begin{array}{l}\mathbf{2 1} \\
16 \\
11\end{array}$ & $\begin{array}{c}\mathbf{4 1} \\
10 \\
5\end{array}$ & $\begin{array}{c}12 \\
\text { nd } \\
8\end{array}$ \\
\hline Freshwater & $\begin{array}{l}\text { Stephanodiscus } \\
\text { Melosira }\end{array}$ & $\begin{array}{c}17 \\
8\end{array}$ & $\begin{array}{c}4 \\
\text { nd }\end{array}$ & $\begin{array}{c}5 \\
\text { nd }\end{array}$ & $\begin{array}{l}\text { nd } \\
\text { nd }\end{array}$ & $\begin{array}{l}\text { nd } \\
\text { nd }\end{array}$ & $\begin{array}{l}16 \\
\text { nd }\end{array}$ \\
\hline Marine \& Freshwater & Cyclotella & 17 & nd & 5 & 16 & 17 & 52 \\
\hline
\end{tabular}




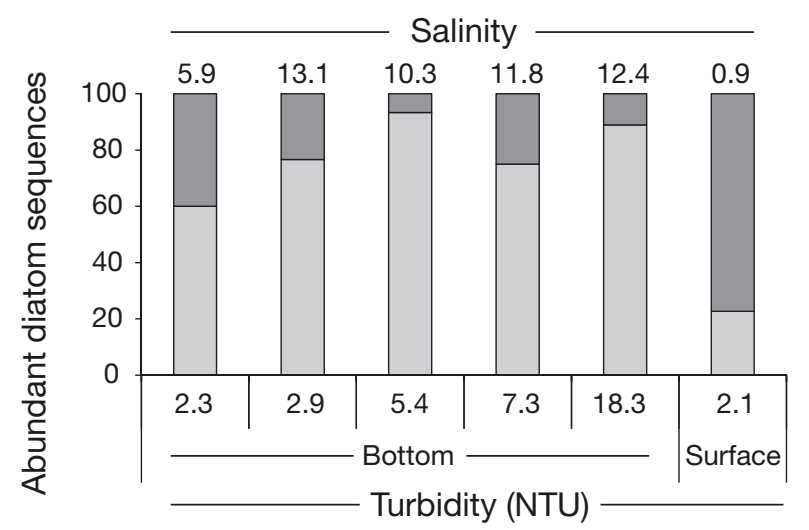

Fig. 4. The proportion of clones from abundant marine ( $\square)$ and freshwater ( $\square$ ) diatom 18S rRNA gene sequences within clone libraries of DNA extracted from samples collected over increasing turbidities in surface and bottom waters. Samples were collected in August 2007 in the Columbia River estuary south channel throughout a spring flood tide estuarine turbidity maximum (ETM). Salinity and turbidity values are given at the top and bottom of the figure, respectively. The data show the dominance of freshwater diatom sequences in low turbidity surface water and the abundance of marine diatom sequences in higher salinity bottom waters. Data used for this analysis is given in Table 2

freshwater phytoplankton community. Thus, the molecular findings presented here support the notion that estuarine surface water particulate OM is mostly composed of freshwater diatoms. These data, however, suggest that the live or recently dead diatoms (those with undamaged DNA) in all our estuarine bottom water samples, and more noticeably in the turbidity maxima, were mostly of marine origin. Therefore, in light of the biogeochemical and molecular data presented in this study, we can conclude that during late summer spring flood tides, the fresh labile particulate OM fraction of the ETM has a marine origin; however, this marine signal is overwhelmed by a large amount of more refractory particulate OM (as discussed above in the discussion), which is likely of freshwater origin (biogeochemically aged chl a-poor POC, the DNA within which is too damaged to be detected by molecular analysis). In support of this idea that older particulate OM does not contain detectable undamaged DNA, it is noteworthy that the highest POC:PN ratio, which is a putative indicator of the potential for DNA degradation vs. POC (because N, and hence DNA, is degraded first), was calculated for the peak ETM bottom water (Table 1), thus indicating significant degradation of the bulk of the particulate OM. This is in keeping with previous reports of enhanced microbial remineralisation in the turbidity maxima of the Columbia River estuary (Crump \& Baross 1996, Crump et al.
1998, Crump et al. 1999). Protists that are highly susceptible to lysis because of environmental pressures (e.g. a change in salinity) would likely be more prone to DNA degradation.

A comparison of molecular and microscopy data is beyond the scope of this study and has, in fact, been discussed thoroughly elsewhere (e.g. McManus \& Katz 2009). However, it is important to note that sequences of the cosmopolitan marine diatom Chaetoceros were not uncovered in our clone libraries, while microscopy-based analyses have reported the presence of this taxon in the Columbia River estuary salt wedge and plume (Haertel et al. 1969, Amspoker \& McIntire 1986, P. Kahn unpubl.). This absence likely highlights differences in the levels of detection achieved between the 2 methods. For example, 400 species of this diatom have been described based on morphological characteristics, while only 49 smallsubunit ribosomal gene sequences related to 24 species (or strains) of this protist were deposited in the NCBI database on 5 August 2010. Nonetheless, in accordance with recent molecular studies from a range of aquatic systems (e.g. Diez et al. 2001, LópezGarcía et al. 2001, Moon-van der Staay et al. 2001, Savin et al. 2004, Lefranc et al. 2005), the present study detected higher levels of protist diversity at the class level by 18S rRNA gene sequencing than by light microscopy; for example, the presence of microeukaryotes such Myrionecta rubra or Katablepharis (see below in the discussion) were only uncovered in clone libraries.

Our samples were collected during a bloom of the photosynthetic ciliate Myrionecta rubra in the Columbia River estuary (Herfort et al. 2011). Interestingly, relatively high proportions of $M$. rubra sequences were detected in pre- and increasing ETM bottom waters (23 and 15\%, respectively; Fig. 3), although this ciliate was not observed by microscopy in any of our samples and the concentrations of its diagnostic cryptophyte chloroplast pigment, alloxanthin (Goodwin 1971), remained low in most of the samples represented in our dataset (0.03-0.06 $\mu \mathrm{g}$ $\mathrm{l}^{-1}$ ) (Table 1). To place these numbers into perspective, in a surface water sample that was collected in the north channel of the estuary on 21 August 2007 and which also contained no visible M. rubra cells by light microscopy (Herfort et al. 2011), the proportion of $M$. rubra sequences in the 18S rRNA gene clone library was slightly lower $(14 \%)$ but the alloxanthin concentration was more than double $\left(1.9 \mathrm{\mu g} \mathrm{l}^{-1}\right)$ those reported here for bottom waters (Table 1). Thus, these bottom water M. rubra DNA signals are clearly associated with extremely low 
levels of diagnostic pigment. While microscopic observations allowed for only a limited volume of sample for investigation and could thus introduce a bias when compared with molecular measurements, these extremely low concentrations of alloxanthin bolsters the argument that although $M$. rubra DNA was present, it was not associated with photosynthetic cells. It is unlikely that this $M$. rubra DNA signal in pre- and increasing ETM waters was generated from an encysted population (such as has been reported for Antarctic saline lakes during times of low ciliate abundance in the water column; Bell \& Laybourn-Parry 1999) because cysts would be expected to be predominantly found in peak ETM water since ETMs are sites of particle accumulation (unless the cysts were undergoing production during the bloom, in which case, they might not have had time to become established in the sediment). Admittedly, ETMs are dynamic traps characterized by high particle selectivity, with conceivable differences in the timing of maximal accumulation of specific particles relative to the bulk. However, the relatively high proportions of $M$. rubra sequences detected with more freshwater non-turbid conditions (salinity of $0.9-10.3$ and turbidity of 2.1-5.4 NTU) and not with elevated turbidity (Fig. 5) suggest a link between this sequence signal and the on-going $M$. rubra bloom that was occurring at the time in the lower Columbia River estuary rather than a direct association with the ETM event. In support of this,

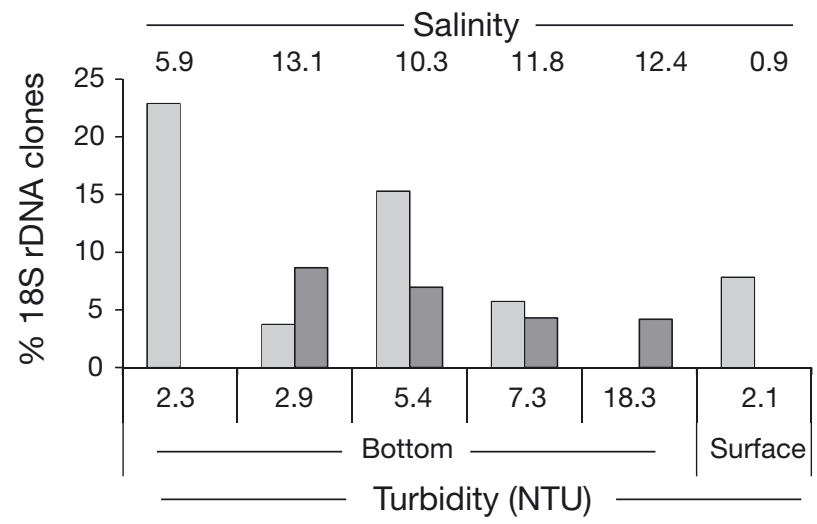

Fig. 5. The proportion of clones containing Myrionecta rubra $(\square)$ and Katablepharis ( $\square$ ) 18S rRNA gene sequences from DNA of surface and bottom water samples collected over increasing turbidities in August 2007 in the Columbia River estuary south channel throughout a spring flood tide estuarine turbidity maximum (ETM). Salinity and turbidity values are given at the top and bottom of the figure, respectively. The data show the presence of Katablepharis sequences in higher turbidity bottom waters, while sequences of $M$. rubra were detected in most samples but not in the peak ETM bottom water (18.3 NTU) the estuarine bottom water $M$. rubra DNA signal detected here had the same internal transcribed spacer (ITS) sequences as that of the Columbia River estuary bloom-forming $M$. rubra, although 5 haplotypes of the ciliate with different ITS sequences have been uncovered on the coast (Herfort et al. 2011). Furthermore, the ETM studied here is a spring tide event and as such is associated with significant particle resuspension from the estuary bottom rather than particle trapping as is typical of neap tide ETMs (Small \& Prahl 2004). This lack of OM accumulation in this spring tide ETM event likely explains why M. rubra sequences were not retrieved in our peak ETM bottom water clone library, although they were detected in all other bottom samples. It is likely that the typical bottom water estuary signal containing dead M. rubra cells found in other low turbidity samples was masked by a strong spring tide ETM signal that did not contain $M$. rubra DNA. The absence of M. rubra DNA during the spring tide resuspension event might also suggest that $M$. rubra might not have been blooming in the lower estuary during the preceding neap tide.

Blooms are highly dynamic, with daytime accumulation of patches of motile and phototactic ciliate cells at or near the surface of the water column, thus creating impressive red tides (Lindholm 1985, Fenchel \& Hansen 2006); however, cell abundance deeper in the water column may be much reduced. Hence, it is not surprising that high numbers of intact Myrionecta rubra cells were not detected by microscopy or pigment analysis of bottom waters, although our bottom water samples were collected during a bloom period (and red water surface patches were observed at this site several times that day). The molecular method seems to be a more sensitive approach for the detection of dead M. rubra cells (either intact cells that have 'lost' their cryptophyte chloroplasts and their readily identifiable shape, or lysed cells that have released floating or particle-attached $M$. rubra free DNA), and thus appears to be an essential tool for establishing sources of biogeochemical inputs to estuaries. Therefore, in contrast to most biogeochemical studies, our data suggests transient input of autochthonous OM (from M. rubra red tide bloom decay) to the Columbia River estuarine bottom OM pool. This input of autochthonous OM might be particularly important for the overall Columbia River estuary OM budget since the late summer $M$. rubra bloom is a recurrent event that affects the entire lower estuary (Herfort et al. 2011).

A few sequences (4 to $9 \%$, Fig. 3) of the small $(5 \mu \mathrm{m})$ colorless heterotrophic flagellate Katable- 
pharis were uncovered in several of our clone libraries as the ETM event developed (from increasing to post-ETM bottom waters). This flagellate has been shown to be a prevalent Columbia River midsalinity estuary microbial eukaryote in April 2007 and 2008, representing half of all protist 18S rRNA gene clone library sequences (P. Kahn unpubl.). Although Katablepharis has been found in marine, estuarine, and freshwater environments (Ploug et al. 2002, Domaizon et al. 2003, Slapeta et al. 2006), a riverine origin in the summer can be ruled out because sequences of the flagellate were neither detected in the surface freshwaters collected in the south channel of the estuary in August 2007 in our study (surface ETM peak, Figs. 3 \& 5) and that of P. Kahn (unpubl.), nor in the low-salinity pre-ETM bottom water of our time series (Figs. $3 \& 5$ ). Despite being associated with more saline waters in our dataset (salinity of 10.3 to 13.1, Fig. 5), the idea of a marine origin in the summer can also be rejected because sequences of this flagellate were not found in the estuarine non-ETM mid-salinity samples of P. Kahn (unpubl.) in August 2007 (salinity: 14.0, depth: $12.0 \mathrm{~m}$ ) or September 2008 (salinity: 13.6, depth: $0.6 \mathrm{~m})$. This suggests that the presence of Katablepharis sequences discovered in the water as the ETM developed is connected to the ETM event itself; in fact, Katablepharis sequences were associated with higher turbidity bottom waters (Fig. 5). Therefore, Katablepharis DNA seems to be somehow retained (perhaps as cysts) in the Columbia River ETMs during periods when this flagellate is not abundant in the estuary water column. The Columbia River ETMs thus appear to not only be important sites for prokaryotic assemblages, hosting active and unique particleattached bacteria (Crump et al. 1999), but to be also exploited by the unicellular eukaryotic assemblage, acting as refugia for ecologically relevant protists such as the well-known bacterivore Katablepharis.

\section{CONCLUSION}

By adding molecular analysis of protist assemblages to the traditionally used biogeochemical and microscopic approaches to study the OM of waters collected throughout the development of a Columbia River ETM during a late summer spring flood tide, we have uncovered multiple sources contributing to the OM of the ETM. These findings are summarized in Fig. 6. Together, the 3 approaches (biogeochemical, microscopic and molecular) confirm data from prior studies indicating that (1) a large proportion of

\section{Estuary particulate organic matter}

- Freshwater diatoms (refractory)

- Freshwater diatoms (labile)

- Marine diatoms (labile)

- Estuary M. rubra bloom decay (labile)

- Estuary retention of Katablepharis (labile)

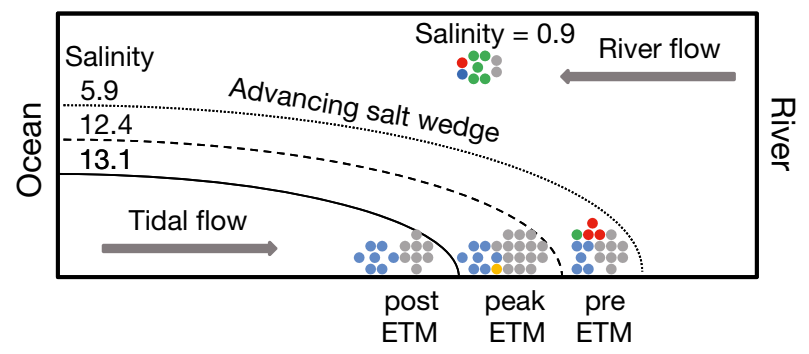

Fig. 6. Schematic of the Columbia River estuary particulate organic matter inputs during a late summer spring flood tide estuarine turbidity maximum (ETM), depicting the majority of organic matter being derived from refractory freshwater inputs in bottom waters as well as labile marine and estuary inputs

the particulate OM in the pre-, peak and post-ETM bottom waters is derived from diatoms as well as refractory OM with chl a-poor POC, and (2) ETMs are traps for particulate OM since more diatoms and POC were detected in the peak ETM than in pre- or post-ETM bottom waters. This refractory particulate OM signal (that can only be examined by biogeochemical, and not by molecular analyses because the constituent DNA appears to be too damaged) is likely the ETM chl a-poor POC of freshwater diatom origin reported by previous biogeochemical studies (grey dots in Fig. 6). In contrast, but still in agreement with prior reports, our biogeochemical, microscopic and nucleotide sequence data have also shown that the low salinity (0.9) surface water collected during the peak of bottom turbidity contained a healthy riverine phytoplankton assemblage dominated by freshwater diatoms, predominantly Cyclotella atomus. A closer inspection of the phylogeny of the diatoms detected by $18 \mathrm{~S}$ rRNA gene sequencing uncovered evidence that the fresh labile particulate OM fraction of all bottom waters collected as the ETM developed had mainly a marine origin, being predominantly derived from the diatom Thalassiosira. Nonetheless, some small, but significant labile freshwater diatom inputs were also present in the lower salinity (5.9) pre-ETM bottom water. These labile freshwater and marine diatom inputs are symbolized in Fig. 6 by green and blue dots, respectively. In addition, DNA from mostly dead Myrionecta rubra cells from red tide bloom decay (either from intact cells that have 'lost' their 
cryptophyte chloroplasts or from free floating or particle-attached DNA released from dead cells) was detected primarily in the pre-ETM bottom water and to a lesser extent in surface peak ETM water. This suggests a transient input of autochthonous OM to the estuarine bottom OM pool and thus challenges the traditional view of the Columbia River estuary as being only characterized by an allochthonous source of OM. Furthermore, the discovery of a few Katablepharis 18S rRNA gene sequences associated with the ETM event during a period when this flagellate is not abundant in the estuary water column indicates that ETMs enable the retention of this microbial eukaryote in the Columbia River estuary. These labile estuarine $\mathrm{OM}$ inputs from $M$. rubra bloom decay and Katablepharis retention are symbolized in Fig. 6 by red and orange dots, respectively. In summary, all the aforementioned findings imply multiple sources of $\mathrm{OM}$ to the Columbia River ETMs, which are thus sites of effective transformation of not only riverborne but also both marine and autochthonous (estuary) OM inputs, as well as refugia for ecologically relevant protists. This study highlights the need to combine molecular analysis and traditional biogeochemical approaches to further our understanding of dynamic aquatic ecosystems. Furthermore, while (1) analysis of protist assemblages past the species level was beyond the scope of this study and (2) population genetics analysis of $M$. rubra based on its ITS sequences did not uncover other ciliate variants in the Columbia River estuary (Herfort et al. 2011), future ecological studies of protist populations at the haplotype or operational taxonomic unit (OTU) level (e.g. Caron et al. 2009) would likely uncover a larger diversity and may in turn provide more in-depth information on sources of OM to this environment.

Acknowledgements. We thank the captain, crew and scientific party of the RV 'Barnes'; M. Selby and V. Campbell (Oregon Health \& Science University, OHSU) for assistance with DNA extraction and clone libraries construction; T. Gregg, M. Sparrow and F. Prahl at Oregon State University for conducting the particulate matter and pigment analyses; and P. Turner (OHSU) for providing the map of the Columbia River estuary. This study was carried out within the context of the Science and Technology Center for Coastal Margin Observation \& Prediction (CMOP) supported by the National Science Foundation (grant no. OCE-0424602).

\section{LITERATURE CITED}

Amspoker MC, McIntire CD (1986) Effects of sedimentary processes and salinity on the diatom flora of the Columbia River estuary. Bot Mar 29:391-399

Bell EM, Laybourn-Parry J (1999) Annual plankton dynamics in an Antarctic saline lake. Freshw Biol 41: 507-519

Caron DA, Countway PD, Savai P, Gast RJ and others (2009) Defining DNA-based operational taxonomic units for microbial-eukaryote ecology. Appl Environ Microbiol 75: 5797-5808

> Crump BC, Baross JA (1996) Particle-attached bacteria and heterotrophic plankton associated with the Columbia River estuary turbidity maxima. Mar Ecol Prog Ser 138: 265-273

Crump BC, Baross JA, Simenstad CA (1998) Dominance of particle-attached bacteria in the Columbia River estuary, USA. Aquat Microb Ecol 14:7-18

> Crump BC, Armbrust EV, Baross JA (1999) Phylogenetic analysis of particle-attached and free-living bacterial communities in the Columbia River, its estuary and the adjacent coastal ocean. Appl Environ Microbiol 65: 3192-3204

Diez B, Pedros-Alio C, Massana R (2001) Study of genetic diversity of eukaryotic picoplankton in different oceanic regions by small-subunit rRNA gene cloning and sequencing. Appl Environ Microbiol 67:2932-2941

> Domaizon I, Viboud S, Fontvieille D (2003) Taxon-specific and seasonal variations in flagellates grazing on heterotrophic bacteria in the oligotrophic Lake Annecy-importance of mixotrophy. FEMS Microbiol Ecol 46:317-329

Fenchel T, Hansen PJ (2006) Motile behavior of the bloomforming ciliate Mesodinium rubrum. Mar Biol Res 2: $33-40$

Frey BE, Lara-Lara R, Small LF (1984) Water column primary production in the Columbia River estuary. Columbia River Estuary Data Development Program, Astoria, OR

Goodwin TW (1971) Algal carotenoids. In: Goodwin TW (ed) Aspects of terpenoid chemistry and biochemistry. Academic Press, London, p 315-356

Haertel L, Osterberg C, Curl H, Park PK (1969) Nutrient and plankton ecology of the Columbia River estuary. Ecology 50:962-978

> Hedges JI, Stern JH (1984) Carbon and nitrogen determinations of carbonate-containing solids. Limnol Oceanogr 29:663-666

> Herfort L, Peterson TD, McCue LA, Crump BC and others (2011) Myrionecta rubra population genetic diversity and its cryptophyte chloroplast specificity in recurrent red tides in the Columbia River estuary. Aquat Microb Ecol 62:85-97

Jay DA (1984) Circulatory processes in the Columbia River Estuary. Columbia River Estuary Data Development Program, Astoria, OR

Jay DA, Musiak JD (1996) Internal tidal asymmetry in channel flows: origins and consequences. In: Pattiaratchi $\mathrm{C}$ (ed) Mixing processes in estuaries and coastal seas. American Geophysical Union, Coastal and Estuarine Sciences Monograph, Washington, DC, p 219-258

Lara-Lara JR, Frey BE, Small LF (1990a) Primary production in the Columbia River estuary. I. Spatial and temporal variability of properties. Pac Sci 44:17-37

Lara-Lara JR, Frey BE, Small LF (1990b) Primary production in the Columbia River estuary. II. Grazing losses, transport and a phytoplankton carbon budget. Pac Sci 44 : 38-50

Lefranc M, Thenot A, Lepere C, Debroas D (2005) Genetic diversity of small eukaryotes in lakes differing by their trophic status. Appl Environ Microbiol 71:5935-5942 
Lindholm T (1985) Mesodinium rubrum - a unique photosynthetic ciliate. Adv Aquat Microbiol 3:1-48

López-Garcia P, Rodriguez-Valera F, Pedros-Alio C, Moreira D (2001) Unexpected diversity of small eukaryotes in deep-sea Antarctic plankton. Nature 409:603-607

McManus GB, Katz LA (2009) Molecular and morphological methods for identifying plankton: what makes a successful marriage? J Plankton Res 31:1119-1129

Moon-van der Staay SY, De Wachter R, Vaulot D (2001) Oceanic 18S rDNA sequences from picoplankton reveal unsuspected eukaryotic diversity. Nature 409:607-610

Neal VT (1972) Physical aspects of the Columbia River and its estuary. In: Pruter AT, Alverson DL (eds) The Columbia River estuary and adjacent ocean waters. University of Washington Press, Seattle, WA, p 19-40

Ploug H, Zimmermann-Timm H, Schweitzer B (2002) Microbial communities and respiration on aggregates in the Elbe Estuary, Germany. Aquat Microb Ecol 27:241-248

Prahl FG, Small LF, Eversmeyer B (1997) Biogeochemical characterization of suspended particulate matter in the Columbia River estuary. Mar Ecol Prog Ser 160: 173-184

Prasad AKSK, Nienow JA, Livingston RJ (1990) The genus Cyclotella (Bacillariophyta) in Choctawhatchee Bay, Florida, with special reference to $C$. striata and C. choctawhatcheeana sp. nov. Phycologia 29:418-436

Savin MC, Martin JL, LeGresley M, Giewat M, RooneyVarga J (2004) Plankton diversity in the Bay of Fundy as measured by morphological and molecular methods. Microb Ecol 48:51-65

Simenstad CA, Small LF, McIntire CD (1990) Consumption processes and food web structure in the Columbia River Estuary. Prog Oceanogr 25:271-297

Simenstad CA, Morgan CA, Cordell JR, Baross JA (1994) Flux, passive retention, and active residence of zooplankton in Columbia River estuarine turbidity maxima. In: Dyer KR, Orth BJ (eds) Changes in fluxes in estuaries: implications from science to management. ECSA22/ERF Symp, Plymouth, September 1992. Olsen \& Olsen Press, Fredensborg, p 473-484
Slapeta J, López-García P, Moreira D (2006) Present status of the molecular ecology of kathablepharids. Protist 157: $7-11$

Small LF, Morgan SR (1994) Phytoplankton attributes in the turbidity maximum of the Columbia River Estuary, USA. In: Dyer K, Orth R (eds) Changing particle fluxes in estuaries: implications from science to management. ECSAERF22 Symp, Plymouth, September 1992. Olsen \& Olsen Press, Fredensborg, p 465-472

Small LF, Prahl FG (2004) A particle conveyor belt process in the Columbia River estuary: evidence from chlorophyll $a$ and particulate organic carbon. Estuaries 27:999-1013

Small LF, McIntire CD, MacDonald KB, Lara-Lara JR, Frey BE, Amspoker MC, Winfield T (1990) Primary production, plant and detrital biomass, and particle transport in the Columbia River estuary. Prog Oceanogr 25: $175-210$

Stoermer EF, Smol JP (1999) The diatoms: application for the environmental and earth sciences. Cambridge University Press, Cambridge

Sullivan BE, Prahl FG, Small LF, Covert PA (2001) Seasonality of phytoplankton production in the Columbia River: a natural or anthropogenic pattern? Geochim Cosmochim Acta 65:1125-1139

Utermöhl H (1931) Neue Wege in der quantitativen Erfassung des Planktons (mit besonderer Berücksichtigung des Ultraplanktons). Verh Int Verein Theor Angew Limnol 5:567-596

Utermöhl H (1958) Zur Vervollkommnung der quantitativen Phytoplankton-Methodik. Mitt Int Ver Theor Angew Limnol 9:1-38

> Verardo DJ, Froelich PN, McIntyre A (1990) Determination of organic carbon and nitrogen in marine sediments using the Carlo Erba NA-1500 analyzer. Deep-Sea Res I 37:157-165

> Wright SW, Jeffrey SW, Mantoura RFC, Llewellyn CA, Bjornland T, Repeta D, Welschmeyer N (1991) Improved HPLC method for the analysis of chlorophylls and carotenoids from marine phytoplankton. Mar Ecol Prog Ser 77:183-196 
Appendix. Number of unicellular 18S rRNA gene sequences obtained in this study as well as accession numbers of all sequences

Table A1. Number of unicellular 18S rRNA gene sequences obtained from samples collected in August 2007 in the Columbia River estuary south channel throughout a spring flood tide estuarine turbidity maximum (ETM) that were used for calculating the percentages presented in Fig. 3. Each entry represents consistent EUKA and EUKB sequence BLAST hits. The low coverage for the pre-ETM bottom water clone library (35 sequences) was due to the removal of many copepod sequences

\begin{tabular}{|c|c|c|c|c|c|c|}
\hline $\begin{array}{l}\text { Water layer: } \\
\text { ETM time point: }\end{array}$ & Pre & Increasing & $\begin{array}{l}\text { Bottom } \\
\text { Peak }\end{array}$ & Decreasing & $\overline{\text { Post }}$ & $\begin{array}{c}\text { Surface } \\
\text { Peak }\end{array}$ \\
\hline Diatom & 12 & 23 & 22 & 19 & 41 & 25 \\
\hline Dinophyta & 2 & 10 & 13 & 21 & 10 & 6 \\
\hline Chlorophyta & 2 & 2 & 0 & 5 & 2 & 2 \\
\hline Chrysophyta & 0 & 3 & 2 & 2 & 1 & 4 \\
\hline Dictyochophyta & 2 & 3 & 2 & 2 & 1 & 4 \\
\hline Cryptophyta & 0 & 2 & 1 & 0 & 1 & 3 \\
\hline Myrionecta rubra & 8 & 11 & 0 & 4 & 3 & 5 \\
\hline Katablepharis & 0 & 5 & 2 & 3 & 7 & 0 \\
\hline Other protists & 9 & 13 & 6 & 14 & 15 & 15 \\
\hline
\end{tabular}

Table A2. Accession numbers of partial 18S rRNA gene sequences obtained during this study and submitted to GenBank. ETM: estuarine turbidity maximum

\begin{tabular}{|c|c|c|c|c|c|c|}
\hline \multirow{2}{*}{$\begin{array}{l}\text { Water layer: } \\
\text { ETM time point: }\end{array}$} & & & \multirow{2}{*}{$\begin{array}{l}\text { Bottom } \\
\text { Peak }\end{array}$} & \multirow[b]{2}{*}{ Decreasing } & \multirow[b]{2}{*}{ Post } & \multirow{2}{*}{$\begin{array}{l}\text { Surface } \\
\text { Peak }\end{array}$} \\
\hline & Pre & Increasing & & & & \\
\hline Diatom & $\begin{array}{c}\text { JF275104 - } \\
\text { JF175127 }\end{array}$ & $\begin{array}{c}\text { JF275174 - } \\
\text { JF275219 }\end{array}$ & $\begin{array}{l}\text { JF275318 - } \\
\text { JF275361 }\end{array}$ & $\begin{array}{c}\text { JF275414 - } \\
\text { JF275451 }\end{array}$ & $\begin{array}{c}\text { JF275554 - } \\
\text { JF275635 }\end{array}$ & $\begin{array}{c}\text { JF275716 - } \\
\text { JF275765 }\end{array}$ \\
\hline Dinophyta & $\begin{array}{c}\text { JF275128 - } \\
\text { JF275131 }\end{array}$ & $\begin{array}{c}\text { JF275220 - } \\
\text { JF275239 }\end{array}$ & $\begin{array}{c}\text { JF275362 - } \\
\text { JF275387 }\end{array}$ & $\begin{array}{c}\text { JF275452 - } \\
\text { JF275493 }\end{array}$ & $\begin{array}{c}\text { JF275636 - } \\
\text { JF275655 }\end{array}$ & $\begin{array}{c}\text { JF275766 - } \\
\text { JF275777 }\end{array}$ \\
\hline Chlorophyta & $\begin{array}{l}\text { JF275132 - } \\
\text { JF275135 }\end{array}$ & $\begin{array}{c}\text { JF275240 - } \\
\text { JF275243 }\end{array}$ & & $\begin{array}{l}\text { JF275494 - } \\
\text { JF275503 }\end{array}$ & $\begin{array}{c}\text { JF275656 - } \\
\text { JF275659 }\end{array}$ & $\begin{array}{c}\text { JF275778 - } \\
\text { JF275781 }\end{array}$ \\
\hline Chrysophyta & & $\begin{array}{c}\text { JF275244 - } \\
\text { JF275249 }\end{array}$ & $\begin{array}{c}\text { JF275388 - } \\
\text { JF275391 }\end{array}$ & $\begin{array}{l}\text { JF275504 - } \\
\text { JF275507 }\end{array}$ & $\begin{array}{c}\text { JF275660 - } \\
\text { JF275661 }\end{array}$ & $\begin{array}{c}\text { JF275782 - } \\
\text { JF275789 }\end{array}$ \\
\hline Dictyochophyta & $\begin{array}{c}\text { JF275136 - } \\
\text { JF275139 }\end{array}$ & $\begin{array}{c}\text { JF275250 - } \\
\text { JF275255 }\end{array}$ & $\begin{array}{c}\text { JF275392 - } \\
\text { JF275395 }\end{array}$ & $\begin{array}{c}\text { JF275508 - } \\
\text { JF275511 }\end{array}$ & $\begin{array}{l}\text { JF275662 - } \\
\text { JF275663 }\end{array}$ & $\begin{array}{c}\text { JF275790 - } \\
\text { JF275797 }\end{array}$ \\
\hline Cryptophyta & & $\begin{array}{c}\text { JF275256 - } \\
\text { JF275259 }\end{array}$ & $\begin{array}{c}\text { JF275396 - } \\
\text { JF275397 }\end{array}$ & & $\begin{array}{c}\text { JF275664 - } \\
\text { JF275665 }\end{array}$ & $\begin{array}{c}\text { JF275798 - } \\
\text { JF275803 }\end{array}$ \\
\hline Myrionecta rubra & $\begin{array}{c}\text { JF275140 - } \\
\text { JF275155 }\end{array}$ & $\begin{array}{c}\text { JF275260 - } \\
\text { JF275281 }\end{array}$ & & $\begin{array}{c}\text { JF275512 - } \\
\text { JF275519 }\end{array}$ & $\begin{array}{c}\text { JF275666 - } \\
\text { JF275671 }\end{array}$ & $\begin{array}{c}\text { JF275804 - } \\
\text { JF275813 }\end{array}$ \\
\hline Katablepharis & & $\begin{array}{l}\text { JF275282 - } \\
\text { JF275291 }\end{array}$ & $\begin{array}{l}\text { JF275398 - } \\
\text { JF275401 }\end{array}$ & $\begin{array}{c}\text { Jf275520 - } \\
\text { JF275525 }\end{array}$ & $\begin{array}{c}\text { JF275672 - } \\
\text { JF275685 }\end{array}$ & \\
\hline Other protists & $\begin{array}{c}\text { JF275156 - } \\
\text { JF275173 }\end{array}$ & $\begin{array}{c}\text { JF275292 - } \\
\text { JF275317 }\end{array}$ & $\begin{array}{c}\text { JF275402 - } \\
\text { JF275413 }\end{array}$ & $\begin{array}{c}\text { JF275526 - } \\
\text { JF275553 }\end{array}$ & $\begin{array}{c}\text { JF275686 - } \\
\text { JF275715 }\end{array}$ & $\begin{array}{c}\text { JF275814 - } \\
\text { JF275843 }\end{array}$ \\
\hline
\end{tabular}

Editorial responsibility: Philippe Borsa, Montpellier, France
Submitted: February 19, 2011; Accepted: July 18, 2011 Proofs received from author(s): September 28, 2011 